\title{
METHODS TO ESTIMATE LETTUCE EVAPOTRANSPIRATION IN GREENHOUSE CONDITIONS IN THE CENTRAL ZONE OF CHILE
}

\author{
Manuel Casanova P. ${ }^{1 *}$, Ingmar Messing ${ }^{2}$, Abraham Joel ${ }^{2}$, and Alberto Cañete M. ${ }^{1}$
}

\begin{abstract}
This study evaluates five methods to estimate crop evapotranspiration in greenhouse conditions. It compares their performance in relation to the evapotranspiration directly determined from water balance measurements $\left(\mathrm{ET}_{y y s}\right)$ in an irrigated lettuce (Lactuca sativa L.) crop during 9 weeks. Daily values of the reference evapotranspiration (ETo) from Class A pan (CAP), Piche atmometers (ATM), Andersson evaporimeters (ANE), FAO-Radiation (FRE) and FAO-Penman-Monteith (PME) equations were compared. The methods showed similar temporal variations but at different ranges as follows: ANE $<\mathrm{CAP}<\mathrm{FRE}<\mathrm{PME}<\mathrm{ATM}$. Furthemore, ETo had a clear correlation with solar radiation. Crop coefficients $\left(\mathrm{Kc}=\mathrm{ET}_{\text {lys }} / \mathrm{ETo}\right)$ varied somewhat amongst the methods, but trends were identified for two periods: in the first week, the overall mean Kc was $0.3( \pm 0.1)$ and in weeks 2 to 9 on average $0.6( \pm 0.3)$. The greenhouse values of Kc were lower than those generally adopted for lettuce in field conditions. In terms of irrigation design, crop evapotranspiration can be estimated by the methods in this study, on the condition that the appropriate crop coefficients are applied. The fact that ANE showed values closest to those of $\mathrm{ET}_{l y s}$, along with cost and management convenience, makes it an advantageous alternative as compared to the other methods.
\end{abstract}

Key words: evapotranspiration, greenhouse, lettuce, lysimeter, Lactuca sativa.

\section{INTRODUCTION}

Crop cultivation under plastic cover is an important production system in Chile. Preliminary results of INE (2007) show that 1578 ha were cultivated in greenhouses. The need to provide fresh quality products during prolonged periods of the year, along with the optimum use of water under dry and hot climatic conditions have led to the adoption of this technology. In these conditions, the plastic cover of the greenhouses significantly changes the internal radiation balance with respect to the external environmental conditions, especially with regard to absorption and reflection of incident solar radiation. As a consequence, important effects in the evapotranspiration (ET) of the crops are observed. In fact, even the best modern glasshouses reduce light input by at least $30 \%$, which should simultaneously cause a considerable reduction in ET (El Moujabber and Abi Zeid Daou, 1999;

\footnotetext{
${ }^{1}$ Universidad de Chile, Facultad de Ciencias Agronómicas, Casilla 1004, Santiago, Chile.

*Corresponding author (mcasanov@uchile.cl).

${ }^{2}$ Swedish University of Agricultural Sciences, Box 7014. SE-750 07

Uppsala, Sweden.

Received: 29 November 2007.

Accepted: 29 January 2008.
}

Radin et al., 2004). Relative humidity, higher inside than outside a greenhouse, has a similar impact but is balanced by the high temperatures normally registered inside. Lower wind velocity also tends to reduce the exchange of water vapor between the canopy and the atmosphere in a greenhouse. The control strategies for the greenhouse climate, and the models behind them, assume that water and nutrient uptake does not limit plant growth (Kläring, 2001). This assumption will be valid if irrigation and fertilization management are controlled.

The most frequently used devices in Chile to estimate the evaporative demand in field conditions are the Class A pan (CAP) and the Piche Atmometers (ATM). On the other hand, Andersson evaporimeters (ANE) have been successfully used in spatial variability studies of evaporation in arid zones of Africa (Messing et al., 1998; Messing and Akrimi, 1998). The readings registered by all these devices are converted, using adequate factors, into reference evapotranspiration values (ETo). Parallel to these devices, empirical equations have been developed that use climatic parameters to estimate ETo. The Penman-Monteith (PME) equation has been recently recommended by Allen et al. (2006) and López-Urrea et al. (2006), as the sole method to determine ETo, although the FAO-Radiation formula (FRE) has been a widely accepted alternative (Nandagiri and Kovoor, 2006). 
At the field level, these methods give reasonable estimates of the crop water requirements, although they have advantages and disadvantages in specific circumstances (Kassam and Smith, 2001; Turco et al., 2008). PME is complex to use in greenhouses because it uses numerous climatic variables. CAP is a simple method to obtain ETo, although space limitations hinder its use in greenhouse conditions. ANE and ATM indubitably show comparative advantages with respect to the pan and equations given their size, cost, and simple operation.

A lot studies have been performed to compare these methods. Araujo et al. (2005) compared lysimeters and $\mathrm{CAP}$ and found determination coefficients $\left(\mathrm{R}^{2}\right)$ of 0.77 and 0.65. López-Urrea et al. (2006) confronted PME and FRE with lysimeters and observed $\mathrm{R}^{2}$ of 0.92 and 0.82 , respectively, whereas Vaughan et al. (2007) showed $\mathrm{R}^{2}$ around 0.74 (diurnal) and 0.23 (night) between PME and lysimeters. Papaioannou et al. $(1996$; 1998) compared ATM with PME and obtained correlation coefficients (R) ranging from 0.29 to 0.65 (yearly period) and 0.49 to 0.91 (over several years). In the case of ANE, Johansson (1969) reported a $\mathrm{R}$ value of 0.93 with $\mathrm{CAP}$, whereas Messing (1998) compares it with ATM and CAP resulting in $\mathrm{R}^{2}$ values of 0.78 and 0.85 , respectively.

El Moujabber and Abi Zeid Daou (1999) argued that the irrigation design based on climatic data is a very common practice but most coefficients utilized to estimate the crop evapotranspiration (ETc), whether lysimeters, devices, or equations, are mainly valid for outdoor conditions, which are contrasting to those of greenhouses. On the other hand, it is necessary to further develop understanding of factors and processes that occur inside greenhouses, among which ETc, estimated from vegetative areas, is one of the main factors to consider in the calculation of water balances. This is necessary in order to get adequate and opportune estimations of water demand for the irrigation system designs to integrate with other management aspects (crop fertilization, pest and disease control, etc.) in these controlled environments. Sarraf (2004) points out that, in the absence of sufficient local measurements on crop water requirements in greenhouses, it is up till now not clear whether greenhouses require more or less water per unit of product than field cultures. Only a limited number of national publications specialized in this area compare the ETc values for greenhouse irrigated crops using these methods with studies of water balance using lysimeters. Although the use of ANE in greenhouses has not been reported in international research, the other methods in the present study have been evaluated under these conditions for several crops (Fernandes et al., 2003; Blanco and Folegatti, 2003; 2004; Orgaz et al., 2005), although few with lettuce (Galvani et al., 1998).
Lettuce, which is a crop that is sensitive to meteorological variations and excess of rain (Radin et $a l ., 2004)$, represents an interesting case to analyze in controlled greenhouse conditions regarding product quality, mainly uniform plant size at harvest. Navarette et al. (1993) pointed this out as being a fundamental quality parameter, very closely linked to environmental and management variables. Given the absence of national information concerning this species, the objective of this study was to compare the ETc values estimated by different methods (CAP, ATM, ANE, FRE and PME) with the evapotranspiration measured by lysimeters $\left(\mathrm{ET}_{l y s}\right)$, for greenhouse-grown lettuce in the central zone of Chile.

\section{MATERIALS AND METHODS}

This study was carried out at the Antumapu

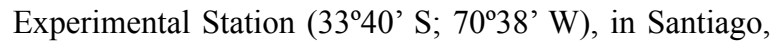
Chile, during the 2002 spring-summer period. The zone has a temperate mesothermal estenothermic semiarid Mediterranean climate (Santibáñez and Uribe, 1992). The thermal regime is characterized by hot dry summers and cold winters with temperatures varying between a maximum mean of $28.2{ }^{\circ} \mathrm{C}$ in January and a minimum mean of $4.4{ }^{\circ} \mathrm{C}$ in July; the frost-free period is 231 days with a mean of 11 frosts per year. Annually, an average of 1621 degree-day and 1147 chill hours are registered. Mean yearly precipitation is $419 \mathrm{~mm}$ with a water deficit of $997 \mathrm{~mm}$ and an eight-month dry period.

A chapel-type greenhouse with a metallic structure facing north-south was used, with dimensions: height 4.0 $\mathrm{m}$, length $18.0 \mathrm{~m}$, and width $11.5 \mathrm{~m}$, and covered with $0.15 \mathrm{~mm}$ transparent polyethylene treated for ultraviolet radiation. Considering solar radiation (Rs) measured for the same period at La Platina Regional Research Center (Instituto de Investigaciones Agropecuarias, INIA) weather station, the mean transmissivity of the cover was $85 \%$. On both sides walls had $0.20 \mathrm{~mm}$ polyethylene curtains which were raised or dropped according to weather fluctuations.

A short-season lettuce hybrid was sown (August 20, 2002) var. capitata, cv. XP 6256 (Seminis Sudamérica S.A., Santiago, Chile) and transplanted (September 30, 2002) at the three-leaf stage. The crop developed during 9 weeks in an artificial substrate composed of an Entic Haploxeroll sandy loam (sand: $53.5 \%$, silt: $32.4 \%$, clay: $14.1 \%$ ), organic residues, and fine sand in a volumetric proportion of $2: 1: 1$, respectively. Physical properties were characterized by extracting five samples of this substrate: bulk density with cylinder, particle density with picnometer, and water retention with pressure devices (Dane and Topp, 2002). 
The $0.15 \mathrm{~m}$-thick substrate was placed on eight $16 \mathrm{x}$ $0.80 \mathrm{~m}$ metal tables, at a height of $0.70 \mathrm{~m}$ from the floor. The six central tables were lined with polyethylene $(0.20$ $\mathrm{mm}$ ) before placing the substrate on it and 10 cylinders connected to recipients were arranged under them to drain water to quantify the water percolation volume (D) in test tubes (precision: $1 \mathrm{~mL}$ ). The transplanted plants were placed in two rows spaced $0.25 \times 0.27 \mathrm{~m}$. Fertilization prior to transplanting was comprised of 80 $\mathrm{kg} \mathrm{N} \mathrm{ha}^{-1}$ (urea), $100 \mathrm{~kg} \mathrm{P}_{2} \mathrm{O}_{5}$ ha $^{-1}$ (triple superphosphate), and $120 \mathrm{~kg} \mathrm{~K}_{2} \mathrm{O}$ ha $^{-1}$ (potassium nitrate). A system of two drip irrigation tapes per table was used over each row of plants, with outlets every $0.20 \mathrm{~m}$ and a discharge of $2.20 \mathrm{~L}$ $\mathrm{h}^{-1} \mathrm{~m}^{-1}$. The irrigation frequency was daily and the applied water volume was measured in an external supply tank (graduated at $1 \mathrm{~cm}$ ), and corresponded to the evaporation of the precedent day measured by means of a standard Class A pan (inside greenhouse). With a calibrated FDR sensor (Frequency Domain Reflectometry, repeatability of $\pm 2 \%$ and operational range between 0 and $100 \%$ ) water content $(\mathrm{W})$ of the substrate was recorded every day before irrigation for each table (15 measurements, at 3 depths).

ETc values, based on calculations of the water balance of the system, were estimated daily $(\Delta t=1)$ using the tables as lysimeters $\left(\mathrm{ET}_{l y s}\right)$. The high porosity of the substrate and the gradient generated by a slight slope of the table bottoms, described by Ben-Gal and Shani (2002), turned the tables into free-drainage lysimeters. In this way, water provided by irrigation (I), stored by the substrate $(\Delta \mathrm{W})$, and drained (D) was calculated daily. The reference evapotranspiration (ETo), which is normally determined in standard conditions (Allen et al., 2006), was estimated on the basis of atmospheric demand measured with the studied devices and empirical equations. In total, one standard Class A pan, 10 Piche atmometers, and two Andersson evaporimeters were used. Table 1 includes the formulae used to define $\mathrm{ET}_{l y s}$ and ETo of each method in this study.

Placement of the Class A pan (CAP) inside the greenhouse, without considering standard reference conditions, can be a first step for rough estimation of water demand when there are no other available methods or weather data are lacking (Baille, 1996). Nevertheless, the use of CAP in these conditions is open to controversy and research on which pan coefficient $(\mathrm{Kp})$ should be used is not conclusive (Fernandes et al., 2003). In this study the CAP was placed at the center of the greenhouse on a wooden structure at table height. A Kp of 0.65 or 0.75 was used, depending on relative humidity $(40-70 \%$ or $>$ $70 \%$, respectively) (Doorenbos and Pruitt, 1976): case A was assumed, with a pan surrounded by a low green crop, windward distance equal to zero and low wind velocity $\left(<2 \mathrm{~m} \mathrm{~s}^{-1}\right)$.

The Piche atmometers were semi-protected from solar radiation; six of them were placed at a fixed height of 1.50 $\mathrm{m}$ above the floor $\left(\mathrm{ATM}_{f}\right)$, the other four were adjusted weekly according to the growth of the lettuce plant and were kept at $0.15 \mathrm{~m}$ above the plants $\left(\mathrm{ATM}_{m}\right)$. ETo $(\mathrm{mm}$ day $^{-1}$ ) for these devices was calculated using the recorded evaporation readings $\left(\mathrm{Ep}, \mathrm{mm} \mathrm{d}^{-1}\right)$ multiplied by two coefficients, both defined by Bouchet (1963): $\alpha$ with a value of 0.27 which considers its semi-protection, and $\rho(\sigma)$ which is a temperature dependent factor.

Table 1. Devices and equations used to estimate evapotranspiration.

\begin{tabular}{lll}
\hline Method & Formula/Equation & Reference
\end{tabular}

Lysimeter $\quad \operatorname{ET}_{\mathrm{lys}}=\frac{\mathrm{I}-(\Delta \mathrm{W}+\mathrm{D})}{\Delta \mathrm{t}}$

$\begin{array}{ll}\text { ATM } & \text { ETo }=\alpha \text { Epi } \rho(\sigma) \\ \text { CAP } & \text { ETo }=\text { Epan Kp } \\ \text { ANE } & \text { ETo }=\text { Ea E } \alpha \\ \text { PME } & \text { ETo }=\frac{0.408 \Delta(\mathrm{Rn}-\mathrm{G})+\gamma \frac{900 \mathrm{u}_{2}\left[\mathrm{e}_{\mathrm{s}}-\mathrm{e}_{2}\right]}{\mathrm{T}+273}}{\Delta+\gamma\left(1+0.34 \mathrm{u}_{2}\right)} \\ & \mathrm{ETo}=\mathrm{b}_{\mathrm{k}}\left(\frac{\Delta}{\Delta+\gamma} \mathrm{R}_{\mathrm{s}}\right)-0.3\end{array}$

Ben-Gal and Shani (2002)

Bouchet (1963)

Doorenbos and Pruitt (1976)

Johansson (1969)

Allen et al. (1994)

Doorenbos and Pruitt (1976)

Frevert et al. (1983)

ET ${ }_{y s}$ : lysimeter; CAP: Class A pan evaporimeter; ATM: Piche atmometer; ANE: Andersson evaporimeter; PME: Penmann Monteith equation; FRE: FAO-Radiation equation. 
The Andersson evaporimeters (ANE) (Figure 1) manufactured with transparent colorless plexiglass, consist of a closed but ventilated cylindrical chamber with a $0.15 \mathrm{~L}$ capacity and an internal water height between 25 and $40 \mathrm{~mm}$; the evaporated water goes out through circular holes located in the upper part of the vessel. Their design is directed to increase flow resistance to simulate the aerodynamic conditions in the leaf-air interphase (Andersson, 1969). Furthermore, they react very quickly to changes in the environmental evaporation demand since they work with a small volume of water. They were placed on $1.5 \mathrm{~m}$-high pedestals inside the greenhouse and ETo $\left(\mathrm{mm} \mathrm{d}^{-1}\right)$ was obtained from the product between the readings (determined with a micrometer with accuracy $0.01 \mathrm{~mm}$ ) of registered evaporation (Ea), as well as an $\mathrm{E} a$ coefficient equal to 0.7 recommended by Johansson (1969). The daily ETo $\left(\mathrm{mm} \mathrm{d}^{-1}\right)$ for each method corresponded to the difference in evaporation readings recorded at $08: 30 \mathrm{~h}$ between two consecutive measurements.

In ETo $\left(\mathrm{mm} \mathrm{d}^{-1}\right)$ estimated through empirical equations (Table 1), the Penman-Monteith equation (PME) derived for $24 \mathrm{~h}$ (Allen et al., 1998) was utilized. It predicts ETo for a hypothetical area of pasture used as reference with a height of $0.12 \mathrm{~m}$, resistance of $70 \mathrm{~s} \mathrm{~m}^{-1}$, and albedo of $23 \%$. It has been used by Pollet and Bleyaert (2000) for greenhouse lettuce with $6 \%$ subestimates. Its structure includes the soil heat flux density $\left(\mathrm{G}, \mathrm{MJ} \mathrm{m}^{-2} \mathrm{~d}^{-1}\right)$ with a zero value over the calculation time increment $(24 \mathrm{~h})$ average daily air temperature $\left(\mathrm{T},{ }^{\circ} \mathrm{C}\right)$ and daily mean of wind speed $\left(\mathrm{u}_{2}, \mathrm{~m} \mathrm{~s}^{-1}\right) 2 \mathrm{~m}$ height, the saturation and actual vapor pressure ( $\mathrm{e}_{\mathrm{s}}$ and $\mathrm{e}_{\mathrm{a}}$ respectively, $\mathrm{kPa}$ ), the saturation vapor pressure deficit $\left(e_{s}-e_{a}\right)$, the slope of the saturation vapor pressure curve $\left(\Delta, \mathrm{kPa}^{\circ} \mathrm{C}^{-1}\right)$, and the psychrometric constant $\left(\gamma, 0.063 \mathrm{kPa}^{\circ} \mathrm{C}^{-1}\right)$. Net radiation at the crop surface $\left(\mathrm{Rn}, \mathrm{MJ} \mathrm{m}^{-2} \mathrm{~d}^{-1}\right)$ was calculated as the difference between the net shortwave radiation (Rns, [1-albedo]·Rs) and net longwave radiation (Rnl) according to the detailed procedure in Doorenbos and Pruitt (1976).

The FAO-Radiation (FRE) equation (Table 1), that links ETo with the solar radiation as evaporation equivalents (Rs, $\mathrm{mm} \mathrm{d}^{-1}$ ) considered the corrections by Frevert et al. (1983) that replace the original nomograms (Nandagiri and Kovoor, 2006). Smith et al. (1998) inform that this equation gives adequate ETo results in high humidity conditions where the aerodynamic element is relatively small, as in greenhouse conditions, whereas results become erratic in dry conditions.

In order to account for all the variables required for PME and FRE, both mechanical anemometer and weather station, with radiation (piranometer) and temperature sensors, were installed at the center of the greenhouse to 1.6 and $2 \mathrm{~m}$ heigths respectively. Two hygrothermographs (calibrated with an aspiration psychrometer) were also utilized. The location of all the devices and instruments are shown in Figure 2 with more details in Table 2.

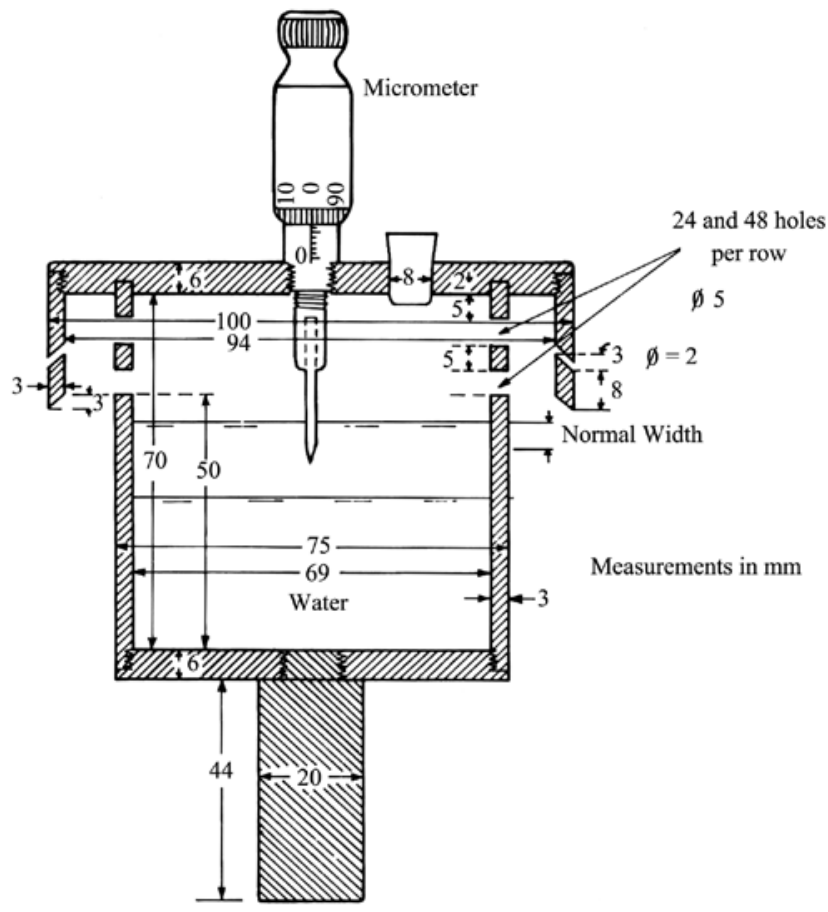

Figure 1. Sketch of Andersson evaporimeter (ANE). 


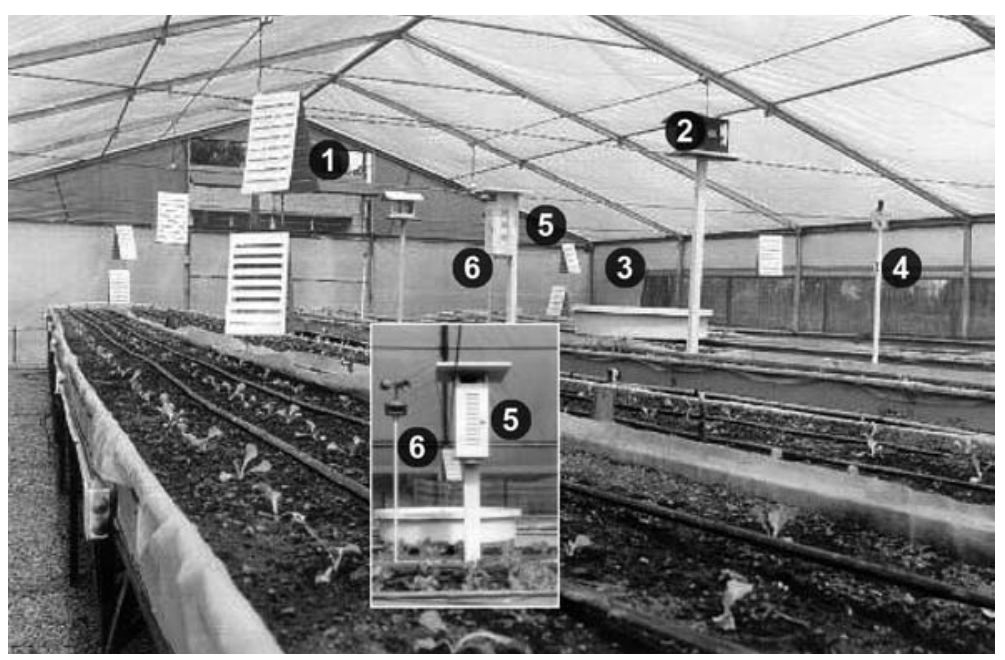

Figure 2. Spatial distribution of devices and instruments inside the greenhouse. 1: Atmometer; 2: Thermohigrograph; 3: Class A pan; 4: Andersson evaporimeter; 5: Meteorological station; 6: Anemometer.

Table 2. Origin of instruments and devices used inside the greenhouse.

\begin{tabular}{lll}
\hline Instrument/device & \multicolumn{1}{c}{ Brand-Model } & \multicolumn{1}{c}{ Location } \\
\hline FDR (Frequency domain reflectometry) & Aquaterr® (M-200). & Fremont, California, USA \\
Piche Atmometer & Casella (CEL) & Bedford, England \\
Andersson Evaporimeter & Swedish University of Agricultural Sciences, & Uppsala, Sweden \\
& Department of Soil Science, Hydrotechnics & \\
Division & Lincoln, Nebraska, USA \\
Weather Station & LI-1200 (Li-Cor Inc.) & Berlin-Steglitz, Germany \\
Mechanical Anemometer & R-Fuess & Baltimore, Maryland, USA \\
Higrothermograph & Bendix Corporation, Friez Instruments & \\
& Division (Model 594) & Drebach, Germany \\
\hline \multirow{2}{*}{ Aspiration Psychrometer } & Fisher ${ }^{\circledR}$ (Assmann Model) & \\
\hline
\end{tabular}

The combined effects of crop transpiration and soil evaporation can be integrated into a unic mean crop coefficient $(\mathrm{Kc})$ that can be considered for normal irrigation planning and management purposes, for the development of basic irrigation schedules, and for most hydrologic water balance studies (Allen et al., 1998). $\mathrm{Kc}$ is consequently estimated for lettuce in greenhouse conditions in the present study.

\section{RESULTS AND DISCUSSION}

Bulk density and particle density of the substrate were 0.94 and $2.89 \mathrm{Mg} \mathrm{m}^{-3}$ respectively, giving a total porosity of $67.5 \%$. During post-transplant period (weeks 1 to 9), water contents (W) close to $33 \mathrm{kPa}$ tension were observed, with a mean of $19.2 \% \pm 1.4$ during the first three weeks (Figure 3) and $21.3 \% \pm 0.8$ for the remainder of the period. Large fluctuations in all measured climatic variables except wind speed were observed inside the greenhouse (Table 3).

The ETo $\left(\mathrm{mm} \mathrm{d}^{-1}\right)$ values determined using the different methods and the values obtained with a lysimeter $\left(\mathrm{ET}_{l y s}\right)$ showed a high daily variability during the assessment period. This degree of oscillation follows the natural fluctuations of the weather variables with direct effects on the measurement devices (Blanco and Folegatti, 2003). However, when analyzing weekly means, the trends are more obvious (Table 4) and closely correlated with variations in solar radiation measured in evapotranspiration equivalents (Figure 4). The values of $\mathrm{ET}_{\text {lys }}$ and ETo for the different methods showed the following relative levels: $\mathrm{ET}_{\text {lys }} \approx \mathrm{ANE}<\mathrm{CAP} \approx \mathrm{FRE} \approx$ $\mathrm{PME}<\mathrm{ATM}_{f} \approx \mathrm{ATM}_{m}$. 

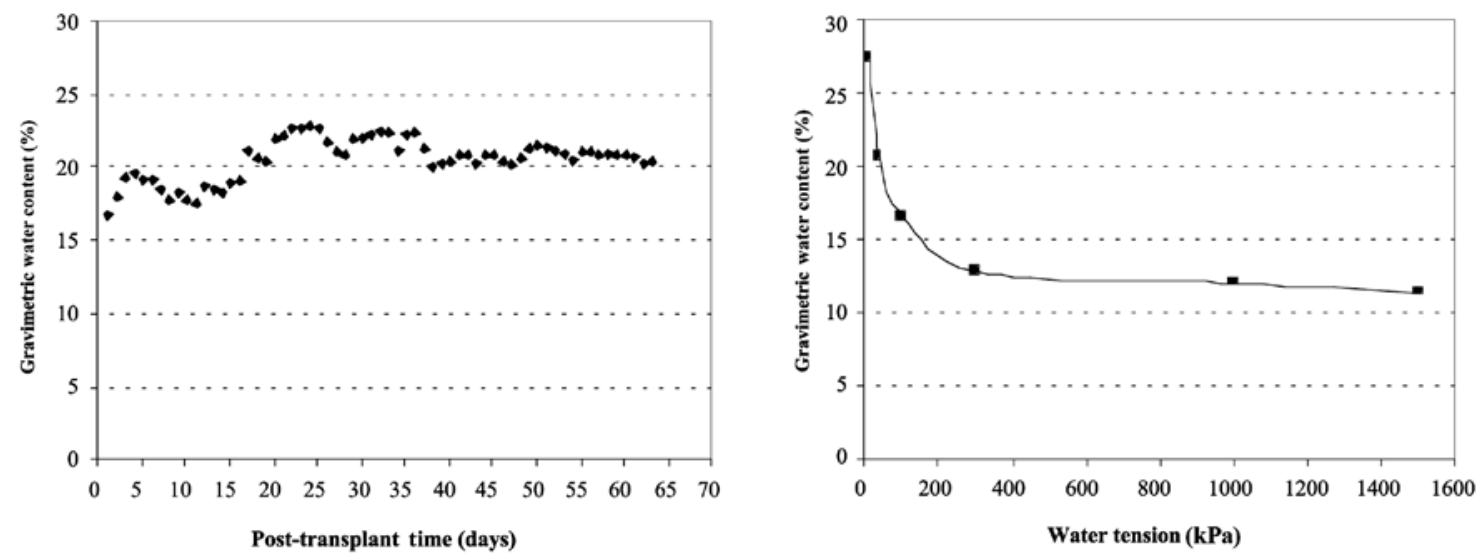

Figure 3. Substrate water content during assay and its water retention curve.

Table 3. Range of climatic variables in the greenhouse during measurement period.

\begin{tabular}{|c|c|c|c|}
\hline \multirow[b]{2}{*}{ Variable } & \multicolumn{3}{|c|}{ Value } \\
\hline & Minimum & Maximum & Mean \pm SD \\
\hline Temperature, ${ }^{\circ} \mathrm{C}$ & 4.0 & 36.8 & $20.0 \pm 2.4$ \\
\hline Solar radiation, $\mathrm{Mj} \mathrm{m}^{-2} \mathrm{~d}^{-1}$ & 3.7 & 23.4 & $17.5 \pm 5.5$ \\
\hline Net radiation, $\mathrm{Mj} \mathrm{m}^{-2} \mathrm{~d}^{-1}$ & 4.1 & 15.1 & $11.3 \pm 3.0$ \\
\hline Relative humidity, \% & 22.5 & 100.0 & $66.3 \pm 8.6$ \\
\hline Vapor pressure deficit, $\mathrm{kPa}$ & 0.2 & 2.4 & $1.3 \pm 0.5$ \\
\hline Wind speed, $\mathrm{m} \mathrm{s}^{-1}$ & 0.0 & 0.1 & $0.0 \pm 0.0$ \\
\hline
\end{tabular}

SD: standard deviation.

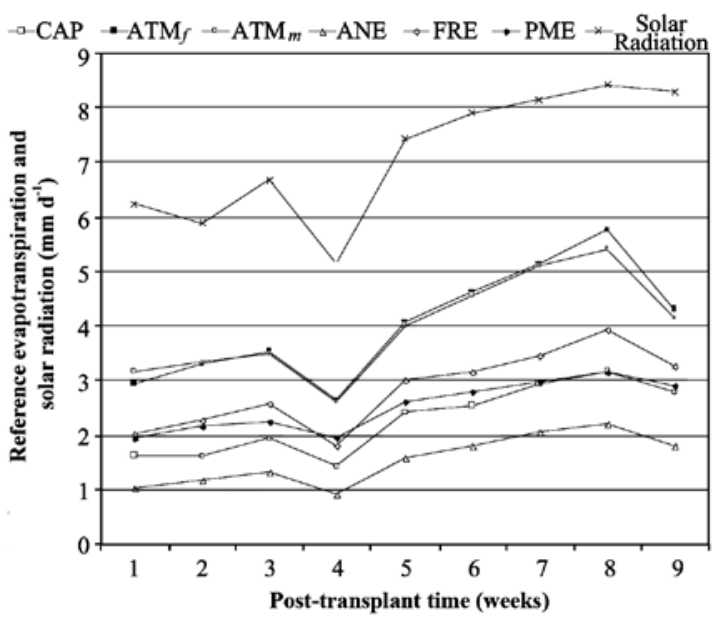

CAP: Class A pan evaporimeter; ATM: fixed $(f)$ and movable $(m)$ Piche atmometer; ANE: Andersson evaporimeter; FRE: FAO-Radiation equation; PME: Penmann Monteith equation.

Figure 4. Weekly mean reference evapotranspiration for different methods and solar radiation inside the greenhouse.
Pan coefficients $(\mathrm{Kp})$ for CAP calculated by Galvani et al. (1998) with the Snyder (1992) empirical formula for greenhouse conditions differ from the Kp values given by Doorenbos and Pruit (1976) that were used in the present investigation (Table 1). Nevertheless, applying the variables measured here with that formula, the results obtained do not differ significantly from those reported in the present study. Moreover, Gundekar et al. (2008) recently reported that $\mathrm{Kp}$ obtained by empirical formulae are not different from those found by Doorenbos and Pruitt (1976), and concluded that the Snyder (1992) formula has the advantage of simplifying the calculation.

A simple correlation analysis of the daily ETo among the different devices and equations, revealed high correlation (R) coefficients (Table 5). Even though the correlation between $\mathrm{ET}_{\text {lys }}$ and ETo based in daily values did not exceed $0.35, \mathrm{R}$ increased to values between 0.72 and 0.86 when weekly values were analyzed.

The results of the $\mathrm{ET}_{\text {lys }} / \mathrm{ETo}$, being an approximation of the crop coefficient $(\mathrm{Kc})$ for lettuce, show the lowest values during the first week (post-transplant) with a mean of $0.3 \pm 0.1$ for the bulk of methods (Table 6). Between weeks 2 and 9, a mean of $0.6 \pm 0.3$ is observed. In this 
Table 4. Daily evapotranspiration, weekly means for different methods.

\begin{tabular}{|c|c|c|c|c|c|c|c|c|c|c|}
\hline \multirow[b]{3}{*}{ Method } & \multicolumn{9}{|c|}{ Mean evapotranspiration } & \multirow[b]{3}{*}{$1-9$} \\
\hline & \multicolumn{9}{|c|}{ Post-transplant time (weeks) } & \\
\hline & 1 & 2 & 3 & 4 & 5 & 6 & 7 & 8 & 9 & \\
\hline & & & & 然 & $-\mathrm{mm} \mathrm{d}$ & $\pm \mathrm{SD}$ & & & & \\
\hline \multicolumn{11}{|c|}{ 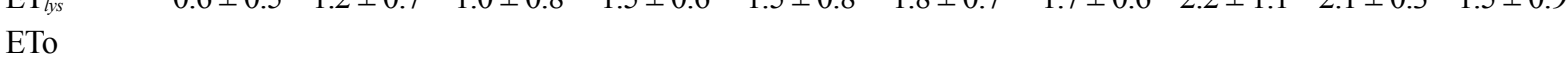 } \\
\hline CAP & $1.6 \pm 0.7$ & $1.6 \pm 0.7$ & $1.9 \pm 1.0$ & $1.4 \pm 0.8$ & $2.4 \pm 0.8$ & $2.5 \pm 0.7$ & $2.9 \pm 0.7$ & $3.2 \pm 0.6$ & $2.8 \pm 0.6$ & $2.3 \pm 1.0$ \\
\hline $\mathrm{ATM}_{f}$ & $3.0 \pm 0.7$ & $3.3 \pm 1.5$ & $3.5 \pm 1.5$ & $2.6 \pm 1.2$ & $4.1 \pm 1.2$ & $4.6 \pm 1.5$ & $5.1 \pm 1.2$ & $5.8 \pm 1.5$ & $4.3 \pm 0.8$ & $4.0 \pm 1.6$ \\
\hline $\mathrm{ATM}_{m}$ & $3.2 \pm 0.7$ & $3.3 \pm 1.5$ & $3.5 \pm 1.4$ & $2.6 \pm 1.2$ & $4.0 \pm 1.1$ & $4.6 \pm 1.5$ & $5.1 \pm 1.1$ & $5.4 \pm 1.4$ & $4.1 \pm 0.9$ & $4.0 \pm 1.5$ \\
\hline ANE & $1.0 \pm 0.4$ & $1.2 \pm 0.5$ & $1.3 \pm 0.6$ & $0.9 \pm 0.6$ & $1.6 \pm 0.5$ & $1.8 \pm 0.5$ & $2.0 \pm 0.4$ & $2.2 \pm 0.4$ & $1.8 \pm 0.4$ & $1.5 \pm 0.7$ \\
\hline PME & $1.9 \pm 0.6$ & $2.2 \pm 0.7$ & $2.3 \pm 0.5$ & $2.0 \pm 0.7$ & $2.6 \pm 0.6$ & $2.8 \pm 0.6$ & $3.0 \pm 0.4$ & $3.2 \pm 0.3$ & $2.9 \pm 0.4$ & $2.5 \pm 0.7$ \\
\hline FRE & $2.0 \pm 1.0$ & $2.3 \pm 1.3$ & $2.6 \pm 1.1$ & $1.8 \pm 1.2$ & $3.0 \pm 1.1$ & $3.1 \pm 1.0$ & $3.5 \pm 0.7$ & $3.9 \pm 0.7$ & $3.3 \pm 0.7$ & $2.8 \pm 1.2$ \\
\hline
\end{tabular}

ET lys: lysimeter; CAP: Class A pan evaporimeter; ATM: fixed $(f)$ and movable $(m)$ Piche atmometer; ANE: Andersson evaporimeter; PME: Penmann Monteith equation; FRE: FAO-Radiation equation; SD: standard deviation.

Table 5. Correlation matrix for reference evapotranspiration (ETo) and lysimeter evapotranspiration $\left(\mathbf{E T}_{l y s}\right)\left(\mathrm{mm} \mathrm{d}^{-1}\right)$, daily and weekly values (in parentheses).

\begin{tabular}{rccccccc}
\hline Method & ET $_{y s}$ & CAP & ATM $_{f}$ & ATM $_{m}$ & ANE & PME & FRE \\
\hline ET $_{\text {lys }}$ & & - & & & & & \\
\multicolumn{1}{c}{ CAP } & 0.34 & & & & & \\
& $(0.80)$ & - & & & & \\
$\operatorname{ATM}_{f}$ & 0.28 & 0.85 & & & \\
& $(0.78)$ & $(0.97)$ & - & & \\
$\operatorname{ATM}_{m}$ & 0.25 & 0.83 & 0.99 & & & \\
& $(0.72)$ & $(0.96)$ & $(0.99)$ & - & & \\
& & & & & & \\
\hline
\end{tabular}

ETo

$\begin{array}{lcccccc}\text { ANE } & 0.31 & 0.89 & 0.96 & 0.95 & & \\ & (0.80) & (0.99) & (0.99) & (0.98) & - & \\ \text { PME } & 0.31 & 0.85 & 0.88 & 0.87 & 0.91 & \\ & (0.79) & (0.99) & (0.98) & (0.97) & (0.99) & - \\ \text { FRE } & 0.35 & 0.84 & 0.89 & 0.87 & 0.90 & 0.97 \\ & (0.86) & (0.99) & (0.97) & (0.95) & (0.99) & (0.98)\end{array}$

ET lys: lysimeter; ETo: Reference evapotranspiration; CAP: Class A pan evaporimeter; ATM: fixed $(f)$ and movable $(m)$ Piche atmometer; ANE: Andersson evaporimeter; PME: Penmann monteith equation; FRE: FAO-Radiation equation.

context, Allen et al. (1998) recommended a single Kc value for greenhouse lettuce, whereas Katerji and Rana (2006) reported that it is possible to find differences of $\pm 40 \%$ between the Kc reported by Allen et al. (1998) and those obtained experimentally, especially in the middle of the growth cycle. These differences are due to the complexity of the coefficient which integrates various functions (Katerji et al., 1991; Testi et al., 2004) such as aerodynamic factors linked to crop height, biological factors related to leaf growth and senescence, physical factors linked to soil evaporation, physiological factors of stomatal response to the air vapor pressure deficit, and agronomic management factors like distance between rows and irrigation system. Furthermore, in greenhouse conditions, the differences in Kc can also be attributed to the size of the greenhouse and the substrate used.

If the ETo values reported in Table 4 were multiplied by $\mathrm{Kc}$ values indicated for each method in Table 6, it would be possible to estimate ETc for greenhouse lettuce. Thus, a linear regression analysis of the paired daily values ETc-ET $\mathrm{F}_{\mathrm{lys}}$ showed a fairly adequate degree of explanation $\left(\mathrm{R}^{2}\right)$ between the methods (Table 7), and furthermore emphazised close to 1:1 relationships between them. Figure 5 graphically shows the estimated ETc for lettuce compared 
with the lysimeter $\left(\mathrm{ET}_{\text {lys }}\right)$ measurement. Consequently, the estimated $\mathrm{Kc}$ values could be appropriate to determine lettuce water requirements in controlled environments and design suitable irrigation schedules to satisfy the water demand of this crop. Movable atmometers $\left(\mathrm{ATM}_{m}\right)$ were excluded from this analysis since their behavior is almost identical to that of fixed atmometers $\left(\mathrm{ATM}_{f}\right)$.

Few studies have been conducted in closed environments such as greenhouses (Fernandes et al., 2003; Blanco and Folegatti, 2003; 2004; Orgaz et al., 2005) and very few for lettuce (Galvani et al., 1998; Radin et al., 2004). Some studies corroborate the results in the present study, whereas others give contrasting results. Arruda et al. (2006), for example, suggested ETo estimation using the following methods, in order of decreasing importance: Penman-Monteith equation (hourly or daily measurements) inside greenhouse, measurements based on solar radiation also inside greenhouse, measurements based on solar radiation outside greenhouse, and ETo outside greenhouse with any method.

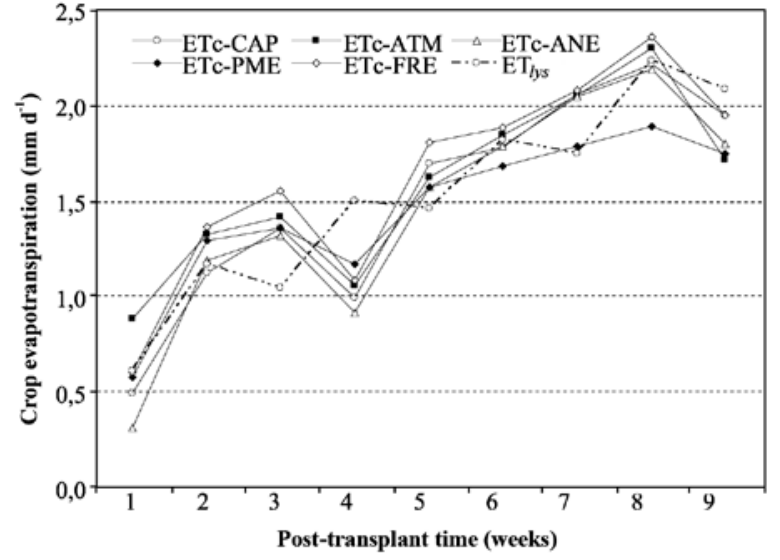

CAP: Class A pan evaporimeter; ATM: Piche atmometer; ANE: Andersson evaporimeter; PME: Penmann Monteith equation; FRE: FAO-radiation equation; $\mathrm{ET}_{\mathrm{lys}}$ : lysimeter.

Figure 5. Weekly mean lettuce evapotranspiration for different methods and solar radiation inside the greenhouse.

Table 6. Weekly mean crop coefficients (Kc) of lettuce using different greenhouse methods.

\begin{tabular}{|c|c|c|c|c|c|c|c|}
\hline \multirow[b]{2}{*}{ Week } & \multicolumn{7}{|c|}{ Crop coefficient ${ }^{\mathrm{a}}$} \\
\hline & CAP & $\mathbf{A T M}_{f}$ & $\mathbf{A T M}_{m}$ & ANE & PME & FRE & Meanh \pm SD \\
\hline 1 & 0.4 & 0.2 & 0.2 & 0.6 & 0.3 & 0.3 & $0.3 \pm 0.1$ \\
\hline 2 & 0.7 & 0.4 & 0.4 & 1.0 & 0.5 & 0.5 & \multirow{9}{*}{$0.6 \pm 0.3$} \\
\hline 3 & 0.5 & 0.3 & 0.3 & 0.8 & 0.5 & 0.4 & \\
\hline 4 & 1.1 & 0.6 & 0.4 & 1.6 & 0.8 & 0.8 & \\
\hline 5 & 0.6 & 0.4 & 0.3 & 0.9 & 0.6 & 0.5 & \\
\hline 6 & 0.7 & 0.4 & 0.3 & 1.0 & 0.6 & 0.6 & \\
\hline 7 & 0.6 & 0.3 & 0.2 & 0.9 & 0.6 & 0.5 & \\
\hline 8 & 0.7 & 0.4 & 0.2 & 1.0 & 0.7 & 0.6 & \\
\hline 9 & 0.7 & 0.5 & 0.3 & 1.2 & 0.7 & 0.6 & \\
\hline 2 to 9 Mean \pm SD & $0.7 \pm 0.1$ & $0.4 \pm 0.1$ & $0.3 \pm 0.1$ & $1.0 \pm 0.2$ & $0.6 \pm 0.1$ & $0.6 \pm 0.1$ & \\
\hline
\end{tabular}

${ }^{a} \mathrm{Kc}=\mathrm{ET}_{l y s} / \mathrm{ETo} ; \mathrm{ET}_{l y s}:$ evapotranspiration using lysimeter; ETo: reference evapotranspiration;

CAP: Class A pan evaporimeter; ATM: fixed $(f)$ and movable $(m)$ Piche atmometer; ANE: Andersson evaporimeter; PME: Penmann Monteith equation; FRE: FAO-radiation equation; SD: standard deviation.

Table 7. Linear regression of daily lysimeter evapotranspiration of lettuce (ET $\left.T_{y s}\right)$ versus estimated values (ETc) for five methods (devices and formulae) during the study period.

\begin{tabular}{lcc}
\hline Method & Equation & Determination coefficient $\left(\mathbf{R}^{2}\right)$ \\
\hline CAP & $\mathrm{ET}_{l y s}=0.98 \mathrm{ETc}$ & 0.76 \\
ATM & $\mathrm{ET}_{l y s}=0.97 \mathrm{ETc}$ & 0.72 \\
ANE & $\mathrm{ET}_{l y s}=1.00 \mathrm{ETc}$ & 0.72 \\
FRE & $\mathrm{ET}_{l y s}=0.92 \mathrm{ETc}$ & 0.73 \\
PME & $\mathrm{ET}_{l y s}=1.05 \mathrm{ETc}$ & 0.80 \\
\hline
\end{tabular}

CAP: Class A pan evaporimeter; ATM: Piche atmometer; ANE: Andersson evaporimeter; FRE: FAO-Radiation equation; PME: Penmann Monteith equation. 


\section{CONCLUSIONS}

Under the conditions of this experiment in greenhouse in the central zone of Chile, the estimation of the reference evapotranspiration (ETo) with the studied devices and equations and without taking into account standard reference conditions, can constitute an approach to estimate crop water requirements.

The variations of $\mathrm{ET}_{\text {lys }}$ and ETo observed over time were large when analyzing on a daily basis whereas on a weekly basis, the variability was reduced and trends more revealed. Thus, the correlations of ETo values between the different devices and equations were high with a $\mathrm{R}$ coefficient fluctuating between 0.83 and 0.99 on a daily basis and from 0.95 to 0.99 on a weekly basis. On the other hand, $\mathrm{R}$ between $\mathrm{ET}_{\text {lys }}$ and ETo fluctuated between 0.25 and 0.35 on a daily basis but reached values between 0.72 and 0.86 for weekly means.

The relative levels of $\mathrm{ET}_{l y s}$ and $\mathrm{ETo}$ values followed the order: $\mathrm{ET}_{l y s} \approx \mathrm{ANE}<\mathrm{CAP} \approx \mathrm{FRE} \approx \mathrm{PME}<\mathrm{ATM}_{f} \approx \mathrm{ATM}_{m}$, and showed a clear correlation with solar radiation.

The use of an Andersson evaporimeter in greenhouses is recommended and adopting a device factor of 0.7 generated ETo almost equal to the actual crop evapotranspiration measured in the lysimeters $\left(\mathrm{ET}_{l y s}\right)$.

Estimated crop coefficient $(\mathrm{Kc})$ based on the $\mathrm{ET}_{\text {lys }} /$ ETo ratio, varied amongst the methods but overall mean values were identified for two growth stages of the crop: first week post-transplant $(0.3 \pm 0.1)$ and second week onwards $(0.6 \pm 0.3)$.

The lettuce evapotranspiration values (ETc) indirectly obtained using devices and equations $(\mathrm{ETo} \cdot \mathrm{Kc})$ were similar to the values measured directly by lettuce lysimeter water balance $\left(\mathrm{ET}_{l y s}\right)$, and showed determination coefficients $\left(\mathrm{R}^{2}\right)$ between 0.72 and 0.80 .

\section{RESUMEN}

Métodos de estimación de la evapotranspiración de un cultivo de lechuga en condiciones de invernadero, zona central de Chile. Este estudio evalúa cinco métodos de estimación de la evapotranspiración de cultivos en condiciones de invernadero. Sus desempeños se evalúan en base a la evapotranspiración determinada directamente a partir de mediciones de balance hídrico $\left(\mathrm{ET}_{l y s}\right.$ ), para un cultivo de lechuga (Lactuca sativa L.) bajo riego y un período de 9 semanas. Se compararon los valores diarios de evapotranspiración de referencia (ETo) provenientes de una bandeja clase A (CAP), atmómetros de Piche (ATM), evaporímetros Andersson (ANE), la ecuación FAO-Radiación (FRE) y la ecuación FAO-Penman-Monteith (PME). Los métodos muestran similares variaciones en el tiempo, pero en los diferentes rangos siguientes: ANE $<$ CAP $<\mathrm{FRE}<\mathrm{PME}<$ ATM. Además, ETo muestra una clara correlación con la radiación solar. Los coeficientes de cultivo $\left(\mathrm{Kc}=\mathrm{ET}_{\text {lys }} / \mathrm{ETo}\right)$ variaron entre métodos pero se identificaron tendencias para dos períodos: en la primera semana el Kc promedio fue de 0,3 $( \pm 0,1)$ y dentro de las semanas 2 a 9 estos valores fueron del orden de 0,6 $( \pm 0,3)$. Los valores de $\mathrm{Kc}$ encontrados en invernadero fueron inferiores a los adoptados para lechuga en condiciones de campo. En términos de diseño de riego, la evapotranspiración del cultivo puede ser estimada si se emplean los métodos de este estudio, con la salvedad que se apliquen los coeficientes de cultivo apropiados. El hecho que ANE muestre los valores más cercanos a los de $\mathrm{ET}_{l y s}$, combinado con su conveniencia en cuanto a costo y manejo, lo convierte en una alternativa ventajosa respecto a los otros métodos.

Palabras clave: evapotranspiración, invernadero, lechuga, lisímetro, Lactuca sativa.

\section{LITERATURE CITED}

Allen, R.G., L.S. Pereira, D. Raes, and M. Smith. 1998. Crop evapotranspiration guidelines for computing crop water requirements. Irrigation and Drainage Paper $\mathrm{N}^{\circ}$ 56. 300 p. FAO, Rome, Italy.

Allen, R.G., L.S. Pereira, D. Raes, y M. Smith. 2006. Evapotranspiración del cultivo. Guías para la determinación de los requerimientos de agua de los cultivos. Cuadernos de Riego y Drenaje $N^{\circ} 56.322$ p. FAO, Roma, Italia.

Andersson, S. 1969. A new evaporimeter. Grundförbättring (Journal of Agricultural Land Improvement) 22:5966.

Araujo, G., F. Bussmeyer, and E. Sakai. 2005. Crop coefficient for irrigated beans derived using three reference evaporation methods. Agric. For. Meteorol. 135:135-143.

Arruda, F.B., R. Pires, E. Sakai, P. Furlani, A. Torre Neto, E. Silva, e R. Calheiros. 2006. Evapotranspiração de referência estimada em estufa com cobertura em polietileno em Campinas. In Proceeding VII Congreso Latinoamericano y del Caribe de Ingeniería Agrícola, V Congreso Internacional de Ingeniería Agrícola, Chillán, Chile. 10-12 de mayo (CD-Rom). Universidad de Concepción, Facultad de Ingeniería Agrícola e Instituto de Investigaciones Agropecuarias, Centro Regional de Investigación Quilamapu, Chillán, Chile. 
Baille, A. 1996. Principle and methods for predicting crop water requirement in greenhouse environments. Cahier Options Méditerranéennes 31:177-187.

Ben-Gal, A., and U. Shani. 2002. A highly conductive drainage extension to control the lower boundary condition of lysimeters. Plant Soil 239:9-17.

Blanco, F., and M. Folegatti. 2003. Evapotranspiration and crop coefficient of cucumber in greenhouse. Rev. Bras. Eng. Agríc. Ambient. 7:285-291.

Blanco, F., and M. Folegatti. 2004. Evaluation of evaporation-measuring equipment for estimating evapotranspiration within a greenhouse. Rev. Bras. Eng. Agríc. Ambient. 8:184-188.

Bouchet, R.J. 1963. Evapotranspiration réelle, évapotranspiration potentielle, et production agricole. Ann. Agron. 14:743-824.

Dane, J.H., and G.C. Topp (eds.) 2002. Methods of soil analysis. Part 4. Physical methods (V1). 1.692 p. American Society of Agronomy, Soil Science Society of America, Madison, Wisconsin, USA.

De Tourdonnet, S., J. Meynard, F. Lafolie, J. RogerEstrade, J. Lagier, and M. Sebillotte. 2001. Nonuniformity of environmental conditions in greenhouse lettuce production increases the risk of $\mathrm{N}$ pollution and lower product quality. Agronomie 21:297-309.

Doorenbos, J., y W. Pruitt. 1976. Las necesidades de agua de los cultivos. Estudio Riego y Drenaje N 24.194 p. FAO, Roma, Italia.

El Moujabber, M., et R. Abi Zeid Daou. 1999. Gestion durable de l'eau pour les cultures protégées au Liban. Cahiers Agricultures 8:309-313.

Fernandes, C., J.E. Cora, and J.A.C. de Araujo. 2003. Reference evapotranspiration inside greenhouses. Sci. Agríc. (Piracicaba, Braz.) 60:591-594.

Frevert, D., R. Hill, and B. Braaten. 1983. Estimate of FAO evapotranspiration coefficients. J. Irrig. Drain. 109:265-270.

Galvani, E., R.T. Dantas, J.F. Escobedo, e E.S. Klosowski. 1998. Parámetros meteorológicos em cultura de Alface (Lactuca sativa L.) cultivada em casas de vegetação com orientações leste-oeste, norte-sul e condições externas. Rev. Brás. Agrometeorol. 6:157-163.

Gundekar, H.G., U.M. Khodke, S. Sarkar, and R.K. Rai. 2008. Evaluation of pan coefficient for reference crop evapotranspiration for semi-arid region. Irrig. Sci. 26:169-175.

INE. 2007. Resultados Preliminares de VII Censo Agropecuario y Forestal de Chile. Temporada 20062007. Cuadro 9. Instituto Nacional de Estadísticas (INE), Santiago, Chile. Disponible en http://www. censoagropecuario.cl/noticias/08/6/10062008.html (Accessed July 2008).
Johansson, W. 1969. The influence of meteorological elements on the evaporation from the Andersson evaporimeter. Grundförbättring (Journal of Agricultural Land Improvement) 22:83-105.

Kassam, A., and M. Smith. 2001. FAO methodologies on crop water use and crop water productivity. Paper CWP-M07. 18 p. FAO, Rome, Italy.

Katerji, N., A. Hamdy, A. Raad, et M. Mastrorilli. 1991. Conséquence d'une contrainte hydrique appliquée à différents stades phénologiques sur le rendement des plantes de poivron. Agronomie 11:679-687.

Katerji, N., and G. Rana. 2006. Modelling evapotranspiration of six irrigated crops under Mediterranean climate conditions. Agric. For. Meteorol. 138:142-155.

Kläring, H.P. 2001. Strategies to control water and nutrient supplies to greenhouse crops. A review. Agronomie 21:311-321.

López-Urrea, F., F. Martín de Santa, C. Fabeiro, and A. Moratalla. 2006. An evaluation of two hourly reference evapotranspiration equations for semiarid conditions. Agric. Water Manage. 86:277-282.

Messing, I. 1998. A simple practical evaporimeter: comparison of Andersson evaporimeter with Class A pan, Piche atmometer, and Penman evaporation. Arid Soil Res. Rehab. 12:275-290.

Messing, I., M. Afors, K. Radkvist, and E. Lewan. 1998. Influence of shelterbelt type on potential evaporation in an arid environment. Arid Soil Res. Rehab. 12:123138.

Messing, I., and K. Akrimi. 1998. Evaporative demand, water use, and crop yield at sheltered and unsheltered sites in an arid environment. Arid Soil Res. Rehab. 12:223-235.

Nandagiri, L., and G. Kovoor. 2006. Performance evaluation of reference evapotranspiration equations across a range of Indian climates. J. Irrig. Drain. Eng. 132:238-249.

Navarette, M., M. Sebillotte, B. Jeannequin, and J. Longuenesse. 1993. Inter-plant variability: a daily criterion for the grower, an open question for the modeler. Acta Hort. (ISHS) 328:211-218.

Orgaz, F., M.D. Fernández, S. Bonachela, M. Gallardo, and E. Federes. 2005. Evapotranspiration of horticultural crops in an unheated plastic greenhouse. Agric. Water Manage. 72:81-96.

Papaioannou, G., S. Kaloudis, and P. Kerkides. 1998. On the proper employment of Piche evaporimeters in estimating evapotranspiration. Int. J. Climatol. 18:1247-1260.

Papaioannou, G., K. Vouraki, and P. Kerkides. 1996. Piche evaporimeter data as a substitute for Penman equation's aerodynamic term. Agric. For. Meteorol. 82(1-4):83-92. 
Pollet, S., and P. Bleyaert. 2000. Application of the PenmanMonteith model to calculate the evapotranspiration of head lettuce (Lactuca sativa L. var. capitata) in glasshouse conditions. Acta Hort. (ISHS) 519:151161.

Radin, B., C. Reisser Júnior, R. Matzenauer, e H. Bergamaschi. 2004. Crescimento de cultivares de alface conduzidas em estufa e a campo. Hort. Bras. 22(2):178-181.

Santibañez, F., y J.M. Uribe. 1992. Atlas agroclimático de Chile. 65 p. Universidad de Chile, Facultad de Ciencias Agrarias y Forestales. Editorial Universitaria, Santiago, Chile.

Sarraf, S. 2004. Irrigation management and maintenance in greenhouse crops in Lebanon. p. 83-93. In Abdelhaq, $\mathrm{H}$. (ed.) Integrated production and protection in greenhouse vegetable crops. Technical Booklet. FAO, Rome, Italy.

Smith, M., R. Allen, and L. Pereira. 1998. Revised FAO methodology for crop-water requirements. p. 5158. In Proceedings of management of nutrients and water in rainfed arid and semi-arid areas, Vienna, Austria. 26-29 May 1997. A Consultants Meeting, FAO/IAEA (Food and Agriculture Organization of the United Nations/International Atomic Energy Agency), Division of Nuclear Techniques in Food and Agriculture, Vienna, Austria.
Snyder, R.L. 1992. Equation for evaporation pan to evapotranspiration conversions. J. Irrig. Drain. Eng. 118:977-980.

Testi, L., F.J. Villalobos, and F. Orgaz. 2004. Evapotranspiration of a young irrigated olive orchard in southern Spain. Agric. For. Meteorol. 121:1-18.

Turco, J.E.P., D. Perecin, e D.L. Pinto Jr. 2008. Influência da acurácia de instrumentos de medidas na comparação de métodos de estimativa da evapotranspiração de referência. Irriga (Botucatu-Brasil) 13(1):63-80.

Vaughan, P.J., T.J. Trout, and J.E. Ayars. 2007. A processing method for weighing lysimeter data and comparison to micrometeorological ETo predictions. Agric. Water Manage. 88:141-146. 